\title{
Alteromonas genovensis sp. nov., isolated from a marine electroactive biofilm and emended description of Alteromonas macleodii Baumann et al. 1972 (Approved Lists 1980)
}

\author{
Ilse Vandecandelaere, ${ }^{1}$ Olivier Nercessian, ${ }^{2}$ Eveline Segaert, ${ }^{1}$ \\ Wafa Achouak, ${ }^{2}$ Alfonso Mollica, ${ }^{3}$ Marco Faimali, ${ }^{3}$ Paul De Vos ${ }^{1}$ \\ and Peter Vandamme ${ }^{1}$
}

Correspondence Ilse Vandecandelaere Ilse.Vandecandelaere@UGent.be

\author{
${ }^{1}$ Laboratorium voor Microbiologie, Vakgroep Biochemie, Fysiologie en Microbiologie, Universiteit \\ Gent, K. L. Ledeganckstraat 35, B-9000 Gent, Belgium \\ ${ }^{2}$ LEMiR, Laboratoire d'Ecologie Microbienne de la Rhizosphère, CNRS-CEA-Université de la \\ Méditerranée, DEVM, Dpt Ecophysiologie Végétale et de Microbiologie/DSV CEA Cadarache, \\ 13108 Saint Paul Lez Durance, France \\ ${ }^{3}$ Instituto di Scienze Marine - Consiglio Nazionale delle Ricerche (ISMAR-CNR), Via de Marini 6, \\ 16149 Genoa, Italy
}

\begin{abstract}
Thirty-five isolates obtained from a marine electroactive biofilm grown on a stainless steel cathode (Genoa, Italy) were investigated by a polyphasic taxonomic approach. Whole-cell fatty acid methyl ester analysis indicated that the isolates belonged to the class Gammaproteobacteria and were closely related or belonging to the genus Alteromonas. Genomic fingerprinting using the BOXPCR primer delineated five clusters of isolates with similar BOX-PCR fingerprints. This study demonstrated that isolates from four of the BOX-PCR clusters belonged to Alteromonas macleodii and that the 14 isolates representing BOX-PCR cluster 1 constituted a novel species, which shared $98.4 \% 16 \mathrm{~S}$ rRNA gene sequence similarity with its nearest phylogenetic neighbour, Alteromonas hispanica. Both phenotypic and genotypic analyses enabled this novel species, for which the name Alteromonas genovensis sp. nov. is proposed, to be differentiated from established species of the genus Alteromonas. The DNA G+C content of Alteromonas genovensis sp. nov. is $44.5 \mathrm{~mol} \%$ and the type strain is LMG $24078^{\top}$ (=CCUG $55340^{\top}$ ).
\end{abstract}

The genus Alteromonas was created by Baumann et al. (1972, 1984) to accommodate Gram-negative, strictly aerobic, heterotrophic rods that are motile by a single polar flagellum. Gauthier et al. (1995) restricted the genus Alteromonas to the type species, Alteromonas macleodii, and transferred all the remaining species into the genus Pseudoalteromonas. Since then, several marine bacteria have been classified as novel Alteromonas species and eight further species have been described: Alteromonas macleodii (Baumann et al., 1972), A. marina (Yoon et al., 2003), A. stellipolaris (Van Trappen et al., 2004), A. litorea (Yoon et al., 2004), A. addita (Ivanova et al., 2005), A. hispanica

The GenBank/EMBL/DDBJ accession numbers for the $16 \mathrm{~S}$ rRNA gene sequences of strains LMG $24078^{\top}$, LMG 24079, LMG 24080, LMG 24081, LMG 24082 and LMG 24083 are AM885866, AM887686, AM885868, AM885867, AM885870 and AM887685, respectively.

DNA-DNA hybridization results and additional electron micrographs are available with the online version of this paper.
(Martínez-Checa et al., 2005), A. tagae (Chiu et al., 2007) and A. simiduii (Chiu et al., 2007).

The genus Alteromonas has gained increasing interest because of potential industrial applications (Hayase et al., 2003; Kodama et al., 1993; Martínez-Checa et al., 2005; Raguenes et al., 2003, 1996; Shiozawa et al., 1993).

Van Trappen et al. (2004) emended the description of the genus Alteromonas by reporting the formation of prosthecae and buds in several species when grown for 3 or more days at low temperatures. The presence of prosthecae and buds enhances the bacterial surface: volume ratio, which facilitates substrate uptake in oligotrophic marine environments (Van Gemerden \& Kuenen, 1984). Marine prosthecate bacteria also play a role in the corrosion of metals as they biologically catalyse the ennoblement of stainless steel surfaces (Baker et al., 2003).

The present study was part of an analysis of the microbial diversity of a marine electroactive biofilm grown on a 
stainless steel cathode (EA-BIOFILMS-508866, NEST) exposed to natural seawater at the ISMAR-CNR Marine Station, located in the port of Genoa, Italy. Stainless steel samples $(25 \times 10 \mathrm{~mm})$, cut from a UNS S 31254 plate ( $1 \mathrm{~mm}$ thick), were drilled, screwed and then treated with emery papers up to P1200. They were immersed in a tank of about $100 \mathrm{l}$ natural seawater at ambient temperature. The seawater was continuously renewed at a rate of about 1.5-2.0 $1 \mathrm{~min}^{-1}$ with water pumped directly from the sea.

The stainless steel electrode was cathodically polarized at $-200 \mathrm{mV} \mathrm{Ag} / \mathrm{AgCl}$ (e.g. Faimali et al., 2008). Current flowing from the ' $n$ 'th polarized sample was calculated from the ohmic drop, $\Delta V_{n}$, measured across the resistor, $R_{n}$, whose value was chosen in such a way that a $\Delta \mathrm{V}_{\mathrm{n}}$ less than $10 \mathrm{mV}$ was measured. During the tests, the cathodic current on all polarized samples was regularly measured and recorded.

The current increased and stabilized at $0.5 \mathrm{~A} \mathrm{~m}^{-2}$ in less than 10 days and microscopic analysis $(400 \times$ magnification using an Olympus BX41 epifluorescence microscope coupled with a UV filter block for DAPI) showed biofilm formation on the cathode. The biofilm was removed from the stainless steel cathode by sonication (Branson 3200) $(90 \mathrm{~s})$ in a sterile plastic tube containing $30 \mathrm{ml} 0.85 \%$ $\mathrm{NaCl}$ solution. Diluted cell suspensions $\left(10^{-1}\right.$ to $\left.10^{-6}\right)$ were inoculated on marine agar (MA; Difco 2216) and incubated aerobically at $20{ }^{\circ} \mathrm{C}$ for several days. Pure cultures were obtained and isolates were stored at $-20{ }^{\circ} \mathrm{C}$ or $-80{ }^{\circ} \mathrm{C}$ using MicroBank vials.

All isolates were tentatively identified using whole-cell fatty acid methyl ester analysis as described by Mergaert et al. (2001). For 35 isolates, comparison of the fatty acid methyl ester profiles with a commercial database (MIS) indicated that they belonged to the class Gammaproteobacteria and that they were closely related or belonged to the genus Alteromonas. These data correlated with Alteromonas-like bacteria constituting considerable fractions of attached marine microbial populations (Acinas et al., 1999; Dang \& Lovell, 2000). In addition, Alteromonas-like bacteria are also frequent producers of extracellular polymer substances, which is important in the context of biofilm formation (Branda et al., 2005; Flemming \& Wingender, 2001). The dominant fatty acids of the 35 isolates were $\mathrm{C}_{10: 0} 3-\mathrm{OH}(2.2 \pm 0.8 \%), \mathrm{C}_{11: 0}$ $3-\mathrm{OH} \quad(1.4 \pm 0.5 \%), \quad \mathrm{C}_{12: 0} \quad(3.3 \pm 1.1 \%), \quad \mathrm{C}_{12: 0} \quad 3-\mathrm{OH}$ $(2.2 \pm 1.2 \%), \mathrm{C}_{14: 0}(3.4 \pm 0.9 \%), \mathrm{C}_{15: 1} \omega 8 c(1.2 \pm 0.6 \%)$, $\mathrm{C}_{16: 0}(19.4 \pm 2.3 \%), \mathrm{C}_{17: 0}(2.6 \pm 0.7 \%), \mathrm{C}_{17: 1} \omega 8 \mathrm{c}(5.7 \pm$ $1.9 \%), \mathrm{C}_{18: 0}(1.1 \pm 0.5 \%), \mathrm{C}_{18: 1} \omega 7 c(13.6 \pm 3.4 \%)$, summed feature 2 (which comprises any combination of $\mathrm{C}_{12: 0}$ aldehyde, an unknown fatty acid of equivalent chain-length 10.928, iso$\mathrm{C}_{16: 1} \mathrm{I}$ and $\mathrm{C}_{14: 0} 3-\mathrm{OH} ; 4.5 \pm 1.7 \%$ ) and summed feature 3 $\left(\mathrm{C}_{16: 1} \omega 7 c\right.$ and/or iso- $\left.\mathrm{C}_{15: 0} 2-\mathrm{OH} ; 30.5 \pm 3.0 \%\right)$; the remaining fatty acids constituted minor fractions only $(<1 \%)$. These results correlated with previous fatty acid analyses of members of the genus Alteromonas (Ivanova et al., 2000).

DNA was extracted according to Pitcher et al. (1989). The genetic diversity among the 35 isolates and type strains of
Alteromonas species was investigated by repetitive DNA-PCR (rep-PCR) fingerprinting using the BOX-A1R-primer (5'CTACGGCAAGGCGACGCTGACG-3') (Versalovic et al., 1994) as described by Rademaker \& De Bruijn (1997) and Rademaker et al. (2000). Numerical analysis of the obtained DNA profiles using the BIONUMERICS 4.61 software (Applied Maths) revealed five clusters of isolates with similar BOXPCR profiles (at least $55.2 \%$ intra-cluster profile similarity) (Fig. 1): cluster 1 (14 isolates), cluster 2 (9 isolates), cluster 3 (5 isolates), cluster 4 (3 isolates) and cluster 5 (4 isolates). The BOX-PCR profiles of these isolates also differed from those of the Alteromonas type strains. Each of the clusters comprised some isolates with virtually indistinguishable profiles suggesting that they represent isolates of the same strain. However, each cluster also comprised isolates with marked differences in their PCR fingerprints, indicating the presence of multiple strains.

The DNA G + C contents of representatives of each BOXPCR cluster were determined. DNA was degraded enzymically into nucleosides as described by Mesbah et al. (1989). The nucleoside mixture obtained was then separated using a Waters Breeze HPLC system and Xbridge Shield RP18 column thermostabilized at $37{ }^{\circ} \mathrm{C}$. The solvent was $0.02 \mathrm{M} \mathrm{NH}_{4} \mathrm{H}_{2} \mathrm{PO}_{4}(\mathrm{pH} 4.0)$ with $1.5 \%$ acetonitrile. Non-methylated lambda phage (Sigma) and Escherichia coli LMG 2093 DNA were used as calibration reference and control, respectively. The DNA G+C contents of representatives of BOX-PCR clusters 1, 2, 3, 4 and 5 were $44.6-45.4 \mathrm{~mol} \%$, which correlated with the DNA $G+C$ data reported for members of the genus Alteromonas (Gauthier et al., 1995) (see Supplementary Table S1 in IJSEM Online).

Almost-complete 16S rRNA gene sequences (1339$1501 \mathrm{bp}$ ) were subsequently obtained for two representatives per BOX-PCR cluster using the universal primers $\mathrm{pA}$ (5'-AGAGTTTGATCCTGGCTCAG-3') and $\mathrm{pH}$ (5'AAGGAGGTGATCCAGCCGCA-3'; Edwards et al., 1989) as described previously (Mergaert et al., 2001). The FASTA program was used to find the most similar sequences in public databases. Sequences were aligned using CLUSTAL_X (Thompson et al., 1997) and edited using BIOEDIT (Hall, 1999) and FORCON (Raes \& Van De Peer, 1999). A neighbour-joining dendrogram was constructed (Saitou \& Nei, 1987) using the TREECON software (Van De Peer \& De Wachter, 1994) (Fig. 2).

The similarity in 16S rRNA gene sequences among isolates of the same BOX-PCR cluster was always $\geqslant 99.1 \%$ (data not shown). These results confirm that isolates with highly similar rep-PCR profiles are closely related (Rademaker \& De Bruijn, 1997; Versalovic et al., 1994).

Representatives of BOX-PCR clusters 2, 3, 4 and 5 exhibited relatively high $16 \mathrm{~S}$ rRNA gene sequence similarities (97.699.2\%) and were $97.6-99.6 \%$ similar to A. macleodii LMG $2843^{\mathrm{T}}$ and A. marina LMG $22057^{\mathrm{T}}$, their nearest phylogenetic neighbours (Fig. 2). BOX-PCR cluster 1 isolates exhibited less than $97 \% 16 \mathrm{~S}$ rRNA gene sequence similarity to the 


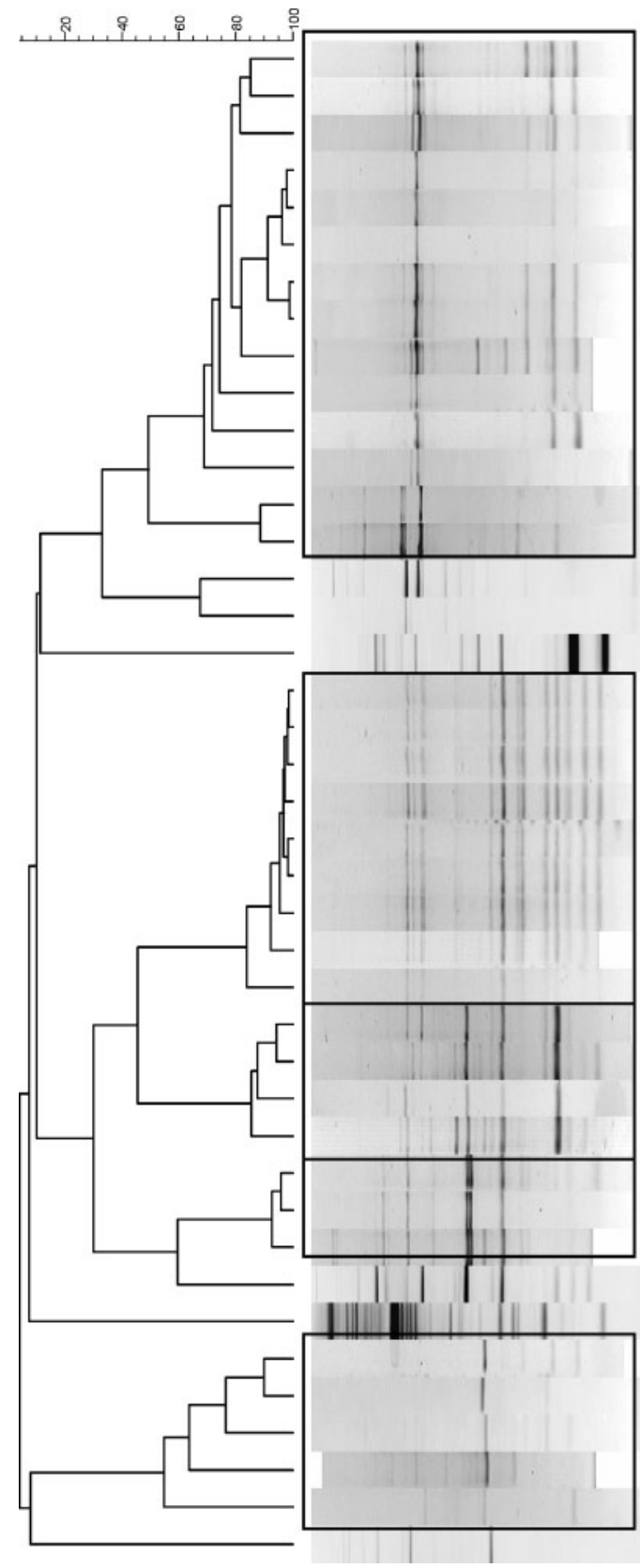

R-28714

R-28729

R-28820

R-28744

R-28813

R-28731

R-28754

R-28776

R-28716

R-28697

R-28713

R-28767

R-25500

R-25502

LMG $21861^{\top}$

LMG $22532^{\top}$

LMG $23846^{\top}$

R-28060

R-28061

R-28062

R-28048

R-28018

R-28039

R-28047

R-28053

R-28032

R-28033

R-28069

R-26190

R-26143

R-28696

R-28740

R-28741

LMG $2843^{\top}$

LMG $22057^{\top}$

R-28017

R-28702

R-28695

R-26142

R-25489

LMG $22958^{\circ}$

Alteromonas genovensis sp.nov.
Alteromonas genovensis sp.nov.
Alteromonas genovensis sp.nov.
Alteromonas genovensis sp.nov.
Alteromonas genovensis sp.nov.
Alteromonas genovensis sp.nov.
Alteromonas genovensis sp.nov.
Alteromonas genovensis sp.nov.
Alteromonas genovensis sp.nov.
Alteromonas genovensis sp.nov.
Alteromonas genovensis sp.nov.
Alteromonas genovensis sp.nov.
Alteromonas genovensis sp.nov.
Alteromonas genovensis sp.nov.
Alteromonas stellipolaris
Alteromonas addita
Alteromonas litorea

LMG $24078^{\top}$

LMG 24079

1

1

1
2

2

2

2

2

2

2

2

2

5

5

5

5

4

4

4

Alteromonas macleodii

Alteromonas marina

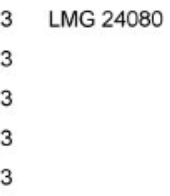

Fig. 1. Dendrogram representing the BOX-PCR fingerprints of Alteromonas genovensis sp. nov. (BOX-PCR cluster 1 ), BOXPCR clusters 2, 3, 4 and 5, and Alteromonas reference strains. Fingerprints were clustered by UPGMA using Pearson's product correlation coefficient.

isolates of BOX-PCR clusters 2, 3, 4 and 5, suggesting that BOX-PCR cluster 1 isolates represent a distinct species (Stackebrandt \& Goebel, 1994). The nearest phylogenetic neighbour of BOX-PCR cluster 1 isolates was A. hispanica with $98.4 \% 16 \mathrm{~S}$ rRNA gene sequence similarity.

DNA-DNA hybridization experiments were performed to elucidate the taxonomic position of the isolates. Two representative isolates per BOX-PCR cluster were selected on the basis of their BOX-PCR fingerprints to include isolates with the most diverse BOX-PCR profiles (Fig. 1). Their genomic relatedness towards A. macleodii LMG $2843^{\mathrm{T}}$, A. hispanica LMG $22958^{\mathrm{T}}$, A. addita LMG $22532^{\mathrm{T}}$, A. stellipolaris LMG $21861^{\mathrm{T}}$, A. litorea LMG $23846^{\mathrm{T}}$ and $A$. marina LMG $22057^{\mathrm{T}}$ was also determined. DNA-DNA hybridization experiments were carried out with photobiotin-labelled probes in microplate wells, as described by Ezaki et al. (1989), using an HTS7000 Bio Assay Reader 


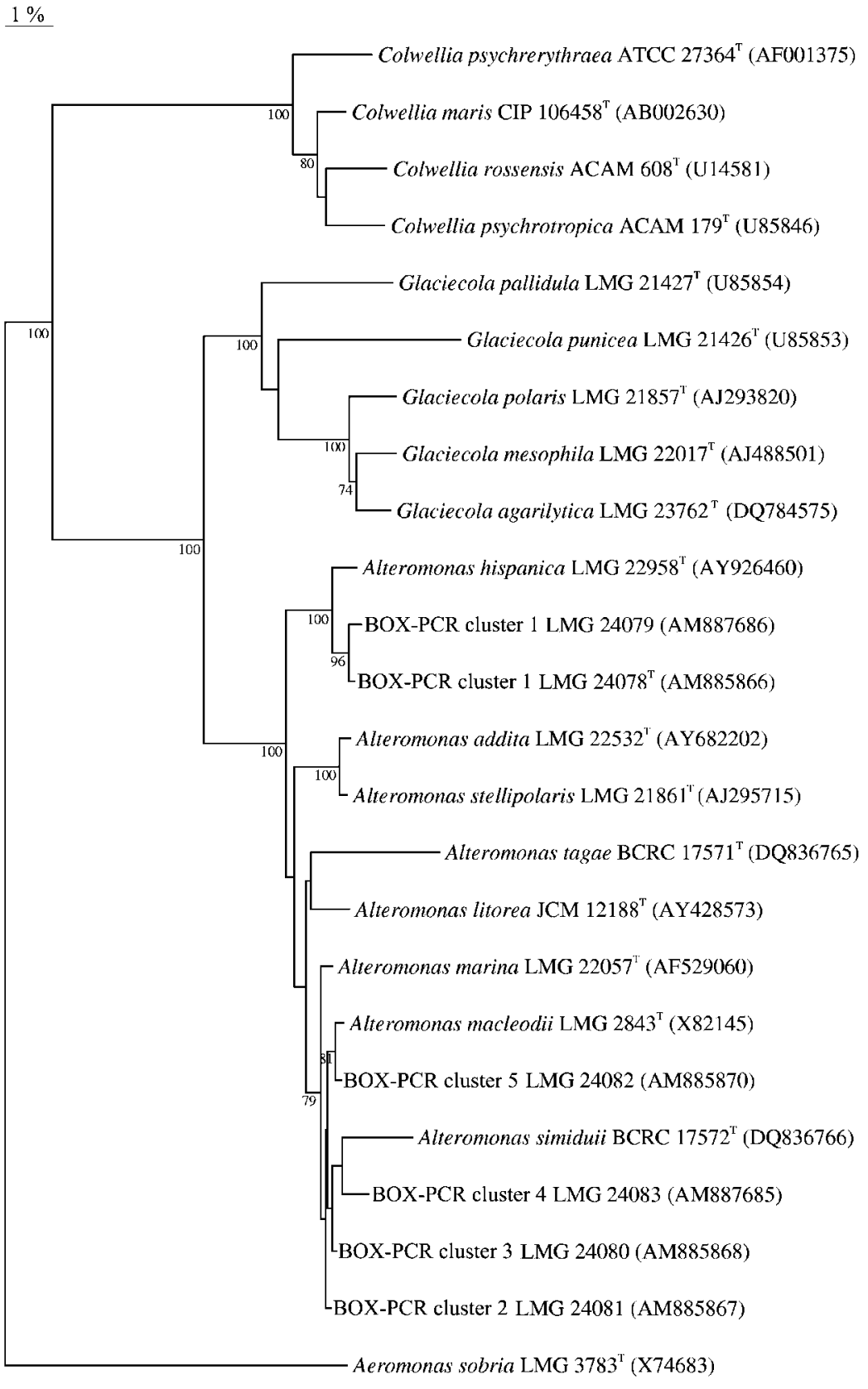

Fig. 2. Dendrogram depicting the $16 \mathrm{~S}$ rRNA gene sequences of Alteromonas genovensis sp. nov., representatives of the BOX-PCR clusters and reference strains of the genera Alteromonas, Colwellia and Glaciecola. Bar, $1 \%$ 16S rRNA gene sequence diversity. Bootstrap values (1000 replicates) above $50 \%$ are shown.
(Perkin Elmer) for the fluorescence measurements. The hybridization temperature was $39{ }^{\circ} \mathrm{C}$ and reciprocal reactions were performed for every pair of strains. DNADNA hybridization values are available in Supplementary Table S1 in IJSEM Online.

The DNA-DNA hybridization values among isolates of the same BOX-PCR cluster were very high, ranging from $80 \pm 1 \%$ (BOX-PCR cluster 5 ) to $98 \pm 2 \%$ (for BOX-PCR cluster 4). This again confirms that the isolates within one BOX-PCR cluster are closely related and belong to the same species (Wayne et al., 1987).

DNA-DNA hybridization values among representatives of BOX-PCR clusters 2, 3, 4 and 5 were moderate to high (a mean value of $66 \pm 1 \%$ was obtained). Isolates of BOX-PCR clusters 2 and 5 revealed high (>90\%) DNA-DNA hybridization values towards $A$. macleodii LMG $2843^{\mathrm{T}}$; BOX-PCR clusters 3 and 4 isolates revealed DNA-DNA hybridization values of $65 \pm 2 \%$ towards $A$. macleodii LMG $2843^{\mathrm{T}}$. DNA-DNA hybridization values towards $A$. marina and all other Alteromonas species examined were low (ranging from $34 \pm 2 \%$ to $43 \pm 1 \%$ ). In addition, DNA-DNA hybridization values of BOX-PCR cluster 1 isolates towards isolates from BOX-PCR clusters 2, 3, 4 and 5 were low (mean of $19 \pm 2 \%$ ), as were the DNA-DNA hybridization values between BOX-PCR cluster 1 isolates and A. hispanica LMG $22958^{\mathrm{T}}(37 \pm 2 \%)$, their nearest phylogenetic neighbour, and all other Alteromonas species examined ( $23 \pm 2 \%$ or less). 
The following morphological, physiological and biochemical tests were performed on one representative isolate per BOX-PCR cluster. Colony morphology was described after 4 days incubation at $20{ }^{\circ} \mathrm{C}$ on MA. Cells were tested for their Gram reaction and catalase and oxidase activities.

Growth on nutrient agar (NA), trypticase soy agar (TSA), $\mathrm{R}_{2} \mathrm{~A}$ and peptone/yeast extract/glucose agar (PYG) (Tan \& Rüger, 1999) was recorded. The optimal $\mathrm{NaCl}$ concentration and the optimal growth temperature were determined using $\mathrm{R}_{2} \mathrm{~A}$ supplemented with $1-20 \% \mathrm{NaCl}$ and incubated for 2 weeks at $20{ }^{\circ} \mathrm{C}$ and $\mathrm{MA}$ incubated at $4-45^{\circ} \mathrm{C}$ for 2 weeks, respectively. The effect of $\mathrm{pH}$ on growth was analysed using marine broth growth medium (Difco 2216) at $\mathrm{pH} 5.0-10.0$ (at intervals of $0.5 \mathrm{pH}$ units) incubated at $20{ }^{\circ} \mathrm{C}$ for 7 days.

Degradation of casein and chitin (Reichenbach \& Dworkin, 1981), DNA [using DNA agar (Difco) containing 0.01\% toluidine blue (Merck)], starch and L-tyrosine (Barrow \& Feltham, 1993) was tested and the reactions were read after 5 days incubation at $20{ }^{\circ} \mathrm{C}$. The isolates were inoculated on Sierra's medium to determine their lipolytic activity and incubated for 10 days at $20{ }^{\circ} \mathrm{C}$ (Sierra, 1957).

The susceptibility to the following antibiotics (Oxoid) was tested on MA plates using the disc diffusion method: ampicillin $(25 \mu \mathrm{g})$, cefoxitin $(30 \mu \mathrm{g})$, gentamicin $(10 \mu \mathrm{g})$, erythromycin $(15 \mu \mathrm{g})$ and kanamycin $(30 \mu \mathrm{g})$. Results were read after 3 days incubation at $20^{\circ} \mathrm{C}$.

Biochemical characteristics from commercial microtest galleries (API ZYM, API 20E and API 20NE) were assessed according to the manufacturer's instructions. API ZYM was read after $4 \mathrm{~h}$ incubation at $20{ }^{\circ} \mathrm{C}$, whereas API $20 \mathrm{E}$ and API 20NE were read after $24 \mathrm{~h}$ incubation at $20{ }^{\circ} \mathrm{C}$.

The cell morphology of BOX-PCR cluster 1 isolate LMG $24078^{\mathrm{T}}$ was determined by transmission electron microscopy. Cells were negatively stained with $2 \%$ uranyl acetate. Ultrathin sections were prepared and analysed as described by Mast et al. (2005) (Fig. 3). Additional electron micrographs are available as Supplementary Fig. S1 in IJSEM Online.

Results of the phenotypic tests are listed in Table 1. Isolates representing BOX-PCR clusters 2, 3, 4 and 5 had the same phenotypic profile as A. macleodii LMG $2843^{\mathrm{T}}$. In addition, phenotypic characteristics clearly discriminated the isolates of BOX-PCR cluster 1 from A. hispanica, their nearest phylogenetic neighbour, and from the other Alteromonas species.

In conclusion, although DNA-DNA hybridization experiments revealed some diversity among isolates of clusters 2 , 3,4 and 5 , this polyphasic taxonomic study demonstrated that they are all most appropriately classified as $A$. macleodii. Isolates of BOX-PCR cluster 1 constituted a novel species within the genus Alteromonas, for which the name Alteromonas genovensis sp. nov. is proposed.

\section{Description of Alteromonas genovensis sp. nov.}

Alteromonas genovensis (ge.no.ven'sis. N.L. fem. adj. genovensis pertaining to Genoa, Italy, where the seawater electroactive biofilms originated).

Cells are Gram-negative rods $(0.9 \times 1.8 \mu \mathrm{m})$, motile by a single polar flagellum. Buds and prosthecae are formed when isolates are grown at lower temperatures $\left(15{ }^{\circ} \mathrm{C}\right)$ for more than 3 days. Prostheca formation is peritrichous and prosthecae are short and straight. The prosthecae are most often found on aggregated cells derived from the bacterial colony. These cell aggregates and, to a lesser extent, isolated bacteria are covered by a layer of fibrillar material. Buds are formed on mother and daughter cells (Fig. 3). Colonies are beige, round and $2 \mathrm{~mm}$ in diameter. The surface is smooth and convex. Growth occurs after 2 days incubation on MA at $20{ }^{\circ} \mathrm{C}$; no growth occurs on TSA, $\mathrm{R}_{2} \mathrm{~A}$ or PYG medium. Moderately halophilic and psychrotolerant. Temperature range for growth is $4-37^{\circ} \mathrm{C}$; no growth occurs at $40{ }^{\circ} \mathrm{C}$ or more. $\mathrm{NaCl}$ range for growth is $2-15 \%$; no growth occurs at 1 or $20 \% \mathrm{NaCl}$. The $\mathrm{pH}$ range for growth is $6.0-8.5$; the optimal $\mathrm{pH}$ for growth is 7.0-8.0. Catalase and oxidase activities are observed. Degrades aesculin and casein, but not tyrosine or DNA. Weakly hydrolyses starch and gelatin; weak lipolysis of Tween 80 is observed. Positive for $\alpha$-chymotrypsin, alkaline phosphatase, leucine arylamidase, cystine arylamidase, acid phosphatase, naphthol-AS-BI-phosphohydrolase, $\beta$-galactosidase, esterase (C4) and esterase lipase (C8) activities. Weak lipase (C14) and trypsin activities. No activity is detected for $\beta$-glucuronidase, $N$-acetyl- $\beta$-glucosaminidase, $\alpha$-mannosidase, $\alpha$-fucosidase, arginine dihydrolase or urease. Nitrate is not reduced to nitrite or nitrogen. No indole production, fermentation of glucose or assimilation of glucose, arabinose, mannose, mannitol, $\mathrm{N}$-acetylglucosa-
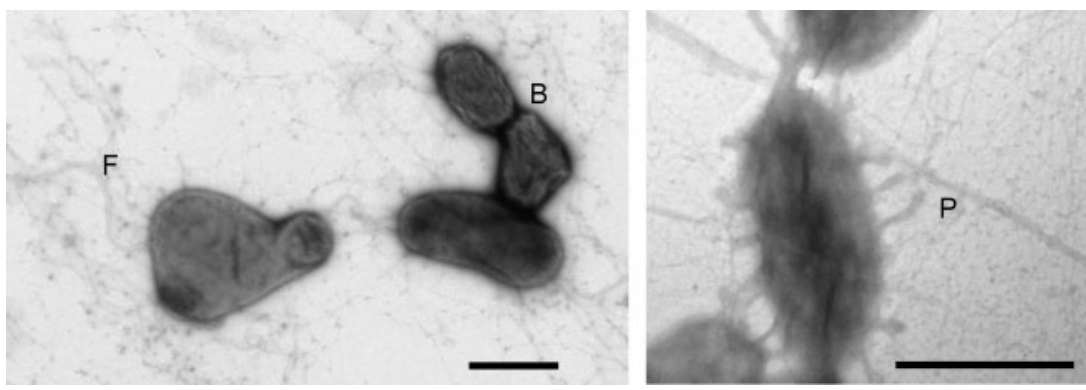

Fig. 3. Electron micrographs of negatively stained cells of strain LMG $24078^{\top}$ showing flagella $(F)$, buds $(B)$ and prosthecae $(P)$. Bars, $1 \mu \mathrm{m}$. 
Table 1. Summary of the results of phenotypic tests for Alteromonas genovensis sp. nov., BOX-PCR clusters $2,3,4$ and 5 , and Alteromonas reference strains

Strains: 1, A. genovensis sp. nov. LMG $24078^{\mathrm{T}}$; 2, A. hispanica LMG $22958^{\mathrm{T}}$ (data from Martínez-Checa et al., 2005); 3, A. litorea LMG 23846 ${ }^{\mathrm{T}}$ (Yoon et al., 2004); 4, A. marina LMG 22057 (Yoon et al., 2003); 5, A. macleodii LMG 2843 ${ }^{\mathrm{T}}$, LMG 24081 (BOX-PCR cluster 2), LMG 24080 (BOX-PCR cluster 3), LMG 24083 (BOX-PCR cluster 4) and LMG 24082 (BOX-PCR cluster 5) (Baumann et al., 1972, 1984; Gauthier et al., 1995; Van Trappen et al., 2004; Yi et al., 2004 and this study). +, Positive; -, negative; W, weakly positive; ND, no data; I, intermediate antibiotic susceptibility.

\begin{tabular}{|c|c|c|c|c|c|}
\hline Characteristic & 1 & 2 & 3 & 4 & 5 \\
\hline Origin & $\begin{array}{c}\text { Marine electroactive } \\
\text { biofilm, Genoa, } \\
\text { Italy }\end{array}$ & $\begin{array}{l}\text { Hypersaline water, } \\
\text { Fuente de Piedra, } \\
\text { Malaga, Spain }\end{array}$ & $\begin{array}{c}\text { Intertidal } \\
\text { sediment, Yellow } \\
\text { Sea, Korea }\end{array}$ & $\begin{array}{c}\text { Seawater, East } \\
\text { Sea, Korea }\end{array}$ & $\begin{array}{l}\text { Seawater, Hawaii + } \\
\text { Marine electroactive } \\
\text { biofilm (Genoa, Italy) }\end{array}$ \\
\hline \multicolumn{6}{|l|}{ Growth in $\mathrm{NaCl}$ at: } \\
\hline $1 \%$ & - & - & + & $\mathrm{ND}$ & + \\
\hline $10 \%$ & + & + & + & + & + \\
\hline $15 \%$ & + & - & - & ND & $\mathrm{W}$ \\
\hline \multicolumn{6}{|l|}{ Growth at: } \\
\hline $4{ }^{\circ} \mathrm{C}$ & + & + & + & + & - \\
\hline $40{ }^{\circ} \mathrm{C}$ & - & - & + & + & + \\
\hline $45^{\circ} \mathrm{C}$ & - & - & + & - & + \\
\hline Growth on TSA & - & - & - & $\mathrm{w}$ & + \\
\hline \multicolumn{6}{|l|}{ Hydrolysis of: } \\
\hline DNA & - & + & - & $\mathrm{ND}$ & + \\
\hline Starch & $\mathrm{w}$ & + & + & + & + \\
\hline Gelatin & $\mathrm{w}$ & + & + & + & + \\
\hline Tyrosine & - & + & + & + & + \\
\hline Casein & + & + & + & + & - \\
\hline Tween 80 & $\mathrm{w}$ & + & + & + & + \\
\hline \multicolumn{6}{|l|}{ Enzymic activity: } \\
\hline$\alpha$-Chymotrypsin & + & - & - & - & - \\
\hline Lipase (C14) & $\mathrm{w}$ & $\mathrm{w}$ & $\mathrm{w}$ & + & + \\
\hline Valine arylamidase & - & $\mathrm{w}$ & w & - & + \\
\hline Trypsin & $\mathrm{w}$ & $\mathrm{W}$ & $\mathrm{w}$ & - & - \\
\hline$\alpha$-Glucosidase & - & - & - & - & + \\
\hline$\alpha$-Galactosidase & - & - & - & - & + \\
\hline$\beta$-Glucosidase & - & - & - & - & + \\
\hline \multicolumn{6}{|l|}{ Susceptibility to: } \\
\hline Ampicillin $(10 \mu \mathrm{g})$ & - & + & I & - & + \\
\hline Erythromycin $(15 \mu \mathrm{g})$ & + & + & + & I & + \\
\hline Gentamicin $(10 \mu \mathrm{g})$ & + & $\mathrm{ND}$ & + & + & + \\
\hline Kanamycin $(30 \mu \mathrm{g})$ & I & + & I & I & + \\
\hline Cefoxitin $(30 \mu \mathrm{g})$ & - & - & - & - & + \\
\hline DNA G $+\mathrm{C}$ content $(\mathrm{mol} \%)$ & 44.5 & 46.3 & 46.0 & 44.5 & 45.2 \\
\hline
\end{tabular}

mine, maltose, potassium gluconate, capric acid, adipic acid, malate, citrate or phenylacetic acid. Resistant to ampicillin $(25 \mu \mathrm{g})$ and cefoxitin $(30 \mu \mathrm{g})$, but not to gentamicin $(10 \mu \mathrm{g})$ or erythromycin $(15 \mu \mathrm{g})$. Intermediately susceptible to kanamycin $(30 \mu \mathrm{g})$. The dominant fatty acids are $\mathrm{C}_{10: 0} 3$ $\mathrm{OH}, \mathrm{C}_{11: 0} 3-\mathrm{OH}, \mathrm{C}_{12: 0}, \mathrm{C}_{12: 0} 3-\mathrm{OH}, \mathrm{C}_{14: 0}, \mathrm{C}_{16: 0}, \mathrm{C}_{17: 0}$, $\mathrm{C}_{17: 1} \omega 8 c, \mathrm{C}_{18: 0}, \mathrm{C}_{18: 1} \omega 7 c$, summed feature 2 and summed feature 3 .

The type strain, LMG $24078^{\mathrm{T}}$ (=CCUG $55340^{\mathrm{T}}$ ), was isolated from a marine electroactive biofilm grown on a stainless steel cathode (Genoa, Italy). A second isolate with a distinct BOX-PCR fingerprint is LMG 24079 (Fig. 1). The DNA G $+C$ content of the type strain is $44.5 \mathrm{~mol} \%$.

\section{Emended description of Alteromonas macleodii Baumann et al. 1972 (Approved Lists 1980)}

The description is as given by Baumann et al. (1972, 1984), Gauthier et al. (1995), Van Trappen et al. (2004) and Yi et al. (2004) with the following additions. Hydrolyses DNA and Ltyrosine. Grows on TSA, but not on NA, $\mathrm{R}_{2} \mathrm{~A}$ or PYG. The $\mathrm{NaCl}$ range for growth is $1-12 \%$; no growth occurs in the presence of $15 \% \mathrm{NaCl}$. Grows at $45{ }^{\circ} \mathrm{C}$. $\mathrm{No} \mathrm{H}_{2} \mathrm{~S}$ production. Susceptible to the following antibiotics: ampicillin $(10 \mu \mathrm{g})$, erythromycin $(15 \mu \mathrm{g})$, gentamicin $(10 \mu \mathrm{g})$, kanamycin $(30 \mu \mathrm{g})$ and cefoxitin $(30 \mu \mathrm{g})$. Lipase (C14), $\alpha$-glucosidase, $\alpha$-galactosidase, $\beta$-glucosidase, cystine arylamidase and $\beta$-galactosidase activities have been recorded, although these 
data conflict with results obtained by Yi et al. (2004). The reason for this discrepancy is unclear.

\section{Acknowledgements}

This work is funded by the European Commission [EA-BIOFILMS508866 (NEST)]. The Fund for Scientific Research - Flanders (FWO Vlaanderen) is acknowledged for financial support of P.V.

\section{References}

Acinas, S. G., Antón, J. \& Rodríguez-Valera, F. (1999). Diversity of free-living and attached bacteria in offshore Western Mediterranean waters as depicted by analysis of genes encoding 16S rRNA. Appl Environ Microbiol 65, 514-522.

Baker, P. W., Ito, K. \& Watanabe, K. (2003). Marine prosthecate bacteria involved in the ennoblement of stainless steel. Environ Microbiol 5, 925-932.

Barrow, G. I. \& Feltham, R. K. A. (1993). Cowan and Steel's Manual for the Identification of Medical Bacteria, 3rd edn. Cambridge: Cambridge University Press.

Baumann, L., Baumann, P., Mandel, M. \& Allen, R. D. (1972). Taxonomy of aerobic marine eubacteria. J Bacteriol 110, 402-429.

Baumann, P., Baumann, L., Bowditch, R. D. \& Beaman, B. (1984). Taxonomy of Alteromonas: A. nigrifaciens sp. nov., nom. rev.; A. macleodii; and A. haloplanktis. Int J Syst Bacteriol 34, 145-149.

Branda, S. S., Vik, S., Friedman, L. \& Kolter, R. (2005). Biofilms: the matrix revisited. Trends Microbiol 13, 20-26.

Chiu, H. H., Shieh, W. Y., Lin, S. Y., Tseng, C. M., Chiang, P. W. \& Wagner-Döbler, I. (2007). Alteromonas tagae sp. nov. and Alteromonas simiduii sp. nov., mercury-resistant bacteria isolated from a Taiwanese estuary. Int J Syst Evol Microbiol 57, 1209-1216.

Dang, H. \& Lovell, C. R. (2000). Bacterial primary colonization and early succession on surfaces in marine waters as determined by amplified rRNA gene restriction analysis and sequence analysis of $16 \mathrm{~S}$ rRNA genes. Appl Environ Microbiol 66, 467-475.

Edwards, U., Rogall, T., Blöcker, H., Emde, M. \& Böttger, E. C. (1989). Isolation and direct complete nucleotide determination of entire genes. Characterization of a gene coding for $16 \mathrm{~S}$ ribosomal RNA. Nucleic Acids Res 17, 7843-7853.

Ezaki, T., Hashimoto, Y. \& Yabuuchi, E. (1989). Fluorometric deoxyribonucleic acid-deoxyribonucleic acid hybridization in microdilution wells as an alternative to membrane filter hybridization in which radioisotopes are used to determine genetic relatedness among bacterial strains. Int J Syst Bacteriol 39, 224-229.

Faimali, M., Chelossi, E., Garaventa, F., Corrà, C., Greco, G. \& Mollica, A. (2008). Evolution of oxygen reduction current and biofilm on stainless steels cathodically polarised in natural aerated seawater. Electrochimica Acta (in press).doi:10.1016/j.electacta.2008.02.115.

Flemming, H. C. \& Wingender, J. (2001). Relevance of microbial extracellular polymeric substances (EPSs) - Part II: technical aspects. Water Sci Technol 43, 9-16.

Gauthier, G., Gauthier, M. \& Christen, R. (1995). Phylogenetic analysis of the genera Alteromonas, Shewanella, and Moritella using genes coding for small-subunit rRNA sequences and division of the genus Alteromonas into two genera, Alteromonas (emended) and Pseudoalteromonas gen. nov., and proposal of twelve new species combinations. Int J Syst Bacteriol 45, 755-761.

Hall, T. A. (1999). BioEdit: a user-friendly biological sequence alignment editor and analysis program for Windows 95/98/NT. Nucleic Acids Symp Ser 41, 95-98.
Hayase, N., Sogabe, T., Itou, R., Yamamori, N. \& Sunamoto, J. (2003). Polymer film produced by a marine bacterium. J Biosci Bioeng 95, 72-76.

Ivanova, E. P., Zhukova, N. V., Svetashev, V. I., Gorshkova, N. M., Kurilenko, V. V., Frolova, G. M. \& Mikhailov, V. V. (2000). Evaluation of phospholipid and fatty acid compositions as chemotaxonomic markers of Alteromonas-like proteobacteria. Curr Microbiol 41, 341-345.

Ivanova, E. P., Bowman, J. P., Lysenko, A. M., Zhukova, N. V., Gorshkova, N. M., Sergeev, A. F. \& Mikhailov, V. V. (2005). Alteromonas addita sp. nov. Int J Syst Evol Microbiol 55, 1065-1068.

Kodama, K., Shiozawa, H. \& Ishii, A. (1993). Alteromonas rava sp. nov., a marine bacterium that produces a new antibiotic, thiomarinol. Ann Rep Sankyo Res Lab 45, 131-136.

Martínez-Checa, F., Béjar, V., Llamas, I., Del Moral, A. \& Quesada, E. (2005). Alteromonas hispanica sp. nov., a polyunsaturated-fatty-acidproducing, halophilic bacterium isolated from Fuente de Piedra, southern Spain. Int J Syst Evol Microbiol 55, 2385-2390.

Mast, J., Nanbru, C., van den Berg, T. \& Meulemans, G. (2005). Ultrastructural changes of the tracheal epithelium after vaccination of day-old chickens with the La Sota strain of Newcastle disease virus. Vet Pathol 42, 559-565.

Mergaert, J., Verhelst, A., Cnockaert, M. C., Tan, T. L. \& Swings, J. (2001). Characterization of facultative oligotrophic bacteria from polar seas by analysis of their fatty acids and $16 \mathrm{~S}$ rDNA sequences. Syst Appl Microbiol 24, 98-107.

Mesbah, M., Premachandran, U. \& Whitman, W. B. (1989). Precise measurement of the $\mathrm{G}+\mathrm{C}$ content of deoxyribonucleic acid by high-performance liquid chromatography. Int J Syst Bacteriol 39, 159-167.

Pitcher, D. G., Saunders, N. A. \& Owen, R. J. (1989). Rapid extraction of bacterial genomic DNA with guanidium thiocyanate. Lett Appl Microbiol 8, 151-156.

Rademaker, J. L. W. \& de Bruijn, F. J. (1997). Characterization and classification of microbes by rep-PCR genomic fingerprinting and computer-assisted pattern analysis. In DNA Markers: Protocols, Applications and Overviews, pp. 151-171. Edited by G. CaetanoAnollés \& P. M. Gresshoff. New York: Wiley.

Rademaker, J. L., Hoste, B., Louws, F. J., Kersters, K., Swings, J., Vauterin, L., Vauterin, P. \& de Bruijn, F. J. (2000). Comparison of AFLP and rep-PCR genomic fingerprinting with DNA-DNA homology studies: Xanthomonas as a model system. Int J Syst Evol Microbiol 50, 665-677.

Raes, J. \& Van De Peer, Y. (1999). ForCon: a software tool for the conversion of sequence alignments. (http://www.ebi.ac.uk/embnet. news/vol6_1/ForCon/body_forcon.html).

Raguenes, G., Pignet, P., Gauthier, G., Peres, A., Christen, R., Rougeaux, H., Barbier, G. \& Guezennec, J. (1996). Description of a new polymer-secreting bacterium from a deep-sea hydrothermal vent, Alteromonas macleodii subsp. fijiensis, and preliminary characterization of the polymer. Appl Environ Microbiol 62, 67-73.

Raguenes, G., Cambon-Bonavita, M. A., Lohier, J. F., Boisset, C. \& Guezennec, J. (2003). A novel, highly viscous polysaccharide excreted by an Alteromonas isolated from a deep-sea hydrothermal vent shrimp. Curr Microbiol 46, 448-452.

Reichenbach, H. \& Dworkin, M. (1981). Introduction to the gliding bacteria. In The Prokaryotes, vol. 1, pp. 315-327. Edited by M. P. Starr, H. Stolp, H. G. Trüper, A. Balows \& H. G. Schlegel. Berlin: Springer.

Saitou, N. \& Nei, M. (1987). The neighbor-joining method: a new method for reconstructing phylogenetic trees. Mol Biol Evol 4, $406-425$. 
Shiozawa, H., Kagasaki, T., Kinoshita, T., Haruyama, H., Domon, H., Utsui, Y., Kodama, K. \& Takahashi, S. (1993). Thiomarinol, a new hybrid antimicrobial antibiotic produced by a marine bacterium. Fermentation, isolation, structure, and antimicrobial activity. J Antibiot (Tokyo) 46, 1834-1842.

Sierra, G. (1957). A simple method for the detection of lipolytic activity of micro-organisms and some observations on the influence of the contact between cells and fatty substrates. Antonie van Leeuwenhoek 23, 15-22.

Stackebrandt, E. \& Goebel, B. M. (1994). Taxonomic note: a place for DNA-DNA reassociation and $16 \mathrm{~S}$ rRNA sequence analysis in the present species definition in bacteriology. Int J Syst Bacteriol 44, 846-849.

Tan, T. L. \& Rüger, H.-J. (1999). Enrichment, isolation, and Biolog metabolic fingerprints of oligotrophic bacteria from the Antarctic Ocean. Arch Hydrobiol Spec Issues 54, 255-272.

Thompson, J. D., Gibson, T. J., Plewniak, F., Jeanmougin, F. \& Higgins, D. G. (1997). The CLUSTAL_X windows interface: flexible strategies for multiple sequence alignment aided by quality analysis tools. Nucleic Acids Res 25, 4876-4882.

Van de Peer, Y. \& De Wachter, R. (1994). TREeCON for Windows: a software package for the construction and drawing of evolutionary trees for the Microsoft Windows environment. Comput Appl Biosci 10, 569-570.

van Gemerden, H. \& Kuenen, J. G. (1984). Strategies for growth and evolution of microorganisms in oligotrophic habitats. In
Heterotrophic Activity in the Sea. NATO Conference Series IV. Marine Sciences, vol. 15, pp. 25-54. Edited by J. E. Hobbie \& P. J. Williams. New York: Plenum.

Van Trappen, S., Tan, T. L., Yang, J., Mergaert, J. \& Swings, J. (2004). Alteromonas stellipolaris sp. nov., a novel, budding, prosthecate bacterium from Antarctic seas, and emended description of the genus Alteromonas. Int J Syst Evol Microbiol 54, 1157-1163.

Versalovic, J., Schneider, M., de Bruijn, F. J. \& Lupski, J. R. (1994). Genomic fingerprinting of bacteria using repetitive sequence-based polymerase chain reaction. Methods Mol Cell Biol 5, 25-40.

Wayne, L. G., Brenner, D. J., Colwell, R. R., Grimont, P. A. D., Kandler, O., Krichevsky, M. I., Moore, L. H., Moore, W. E. C., Murray, R. G. E. \& other authors (1987). International Committee on Systematic Bacteriology. Report of the ad hoc committee on reconciliation of approaches to bacterial systematics. Int J Syst Bacteriol 37, 463-464.

Yi, H., Bae, K. S. \& Chun, J. (2004). Aestuariibacter salexigens gen. nov., sp. nov. and Aestuariibacter halophilus sp. nov., isolated from tidal flat sediment, and emended description of Alteromonas macleodii. Int J Syst Evol Microbiol 54, 571-576.

Yoon, J. H., Kim, I. G., Kang, K. H., Oh, T. K. \& Park, Y. H. (2003). Alteromonas marina sp. nov., isolated from sea water of the East Sea in Korea. Int J Syst Evol Microbiol 53, 1625-1630.

Yoon, J. H., Yeo, S. H., Oh, T. K. \& Park, Y. H. (2004). Alteromonas litorea sp. nov., a slightly halophilic bacterium isolated from an intertidal sediment of the Yellow Sea in Korea. Int J Syst Evol Microbiol 54, 1197-1201. 